\title{
Using Self-Experimentation and Single-Subject Methodology to Promote Critical Thinking
}

\author{
Brian J. Cowley, PhD, BCBA \\ Associate Professor of Psychology \\ Ann Lindgren \\ David Langdon \\ Department of Psychology \\ Park University
}

Critical thinking is often absent from classroom endeavor because it is hard to define (Gelder, 2005) or is difficult to assess (Bissell \& Lemons, 2006). Critical thinking is defined as application, analysis, synthesis, and evaluation (Browne \&

Minnick, 2005). This paper shows how self-experimentation and single-subject methodology can be used to promote many levels of critical thinking in an Applied Behavior Analysis course. Two classroom assignment examples of this process and a grading rubric are provided.

We have all been in a classroom as the professor disseminates information to the class from the podium. Some students listen to the professor; some think about last weekend's fun and others consider future fun. While discussing the importance of the learning environment, Robinson and Kakela (2006) stated: "When students sit passively as their professor delivers information by lecturing ('drone on,' one student called it), they often do not become engaged in their learning" ( $p$. 204). Learning is more than just hearing, rehearsing, and recalling information. There are processes and strategies that students should learn that will assist them in becoming learners over a lifetime. One important skill is critical thinking.

Gelder (2005) argued that all educators at every level should help their students learn to think critically. He indicated that critical thinking is difficult and does not come naturally to people. Bissell and Lemons (2006) indicated that teachers do not know how to define critical thinking, nor do they know how to measure it. Browne and Minnick (2005) generally defined critical thinking as application, analysis, synthesis, and evaluation of a given subject. If teachers want to have their students use critical thinking in the classroom, they must identify processes that are conducive to and design student activities that include these

If teachers want to have their students use critical thinking in the classroom, they must identify processes that are conducive to and design student activities that include these processes. processes.

Bissell and Lemons (2006) developed projects for biology students that required them to use critical thinking skills and then used individualized scoring rubrics to assess critical thinking in those projects. Fisher and Riley (2005) used an application assignment that required nursing students to read the scientific literature, critique what was read, and then apply what they read to the clinical setting. In this paper, we describe a similar process in the field of Behavior Analysis. We used self-experimentation projects (Altman, 1986; Roberts \& Neuringer, 1998) and single-subject methodology (Barlow \& Hersen, 1984) to guide students through a critical thinking process.

\section{I ntroducing Target Behavior and Treatment}

Students enrolled in an upper level psychology class (Applied Behavior Analysis) were given a self-experimentation project. Each student was required to select a behavior of his/her own that he/she wanted to change. The selected behaviors did not include those that result in danger to the student or other people. 
Students were also required to avoid behaviors that were better served by professional therapy. Each targeted behavior needed to be approved by the course instructor.

Once the student identified his/her targeted behavior, he/she started to examine the scientific literature. The purpose was to gain information about their targeted behavior at many different levels, from general information to treatment applications. This review of the literature provided evidence and the student offered his/her own logic as to why they chose the particular treatment procedure. Sometimes students selected previously used methods and added their own modification to the method. This was the beginning of the process of assimilating, analyzing, evaluating, and applying information (a critical thinking process).

\section{Methodological Strategies}

Operational Definition and Behavior Observation

While students reviewed the literature and learned about their targeted behavior, they were trained to operationally define the targeted behavior so that the presence or absence of the targeted behavior could be distinguished. Once this was accomplished, the students were trained in using basic behavior observation strategies. With this information in hand, plus what had

This was the beginning of the process of assimilating, analyzing, evaluating, and applying information (a critical thinking process). been gleaned from the literature, students were then required to design their own observation data systems. This required students to use critical thinking skills. They had acquired information on behavior observation and they had selected their target behavior. They were then required to identify the best observation procedure for measuring their targeted behavior. Often they had to test several different methods before selecting the most appropriate.

\section{Baseline}

While championing the use of single-subject methodology, Barlow and Hersen (1984) argued that it was incumbent on those seeking to change human behavior to identify functional relations between environmental events and targeted behaviors that would not be confused with other available environmental and biological variables. In order to make such an analysis, each student was required to start a baseline. That means they started to observe their targeted behavior using the operational definition and data observation system they had selected. Each student would be required to observe the repeated measure of his/her targeted behavior over time without the selected intervention being in place. The purpose was to look at behavior trends (see figure 1). Students were required to identify a stable pattern of responding before they could intervene. The logic is that over time they would compare baseline levels to treatment levels. This requires the critical thinking process: If you want to increase the rate of responding, you do not intervene during an ascending pattern. Conversely, if you want to decrease the rate of responding, you do not intervene during a decreasing trend. Students were required to bring their graphs each time the class met. They were divided up into treatment teams to discuss the behavior trends that were observed. They used this information as criteria to determine when each intervention should be implemented. These decisions were made under the supervision of the instructor. 

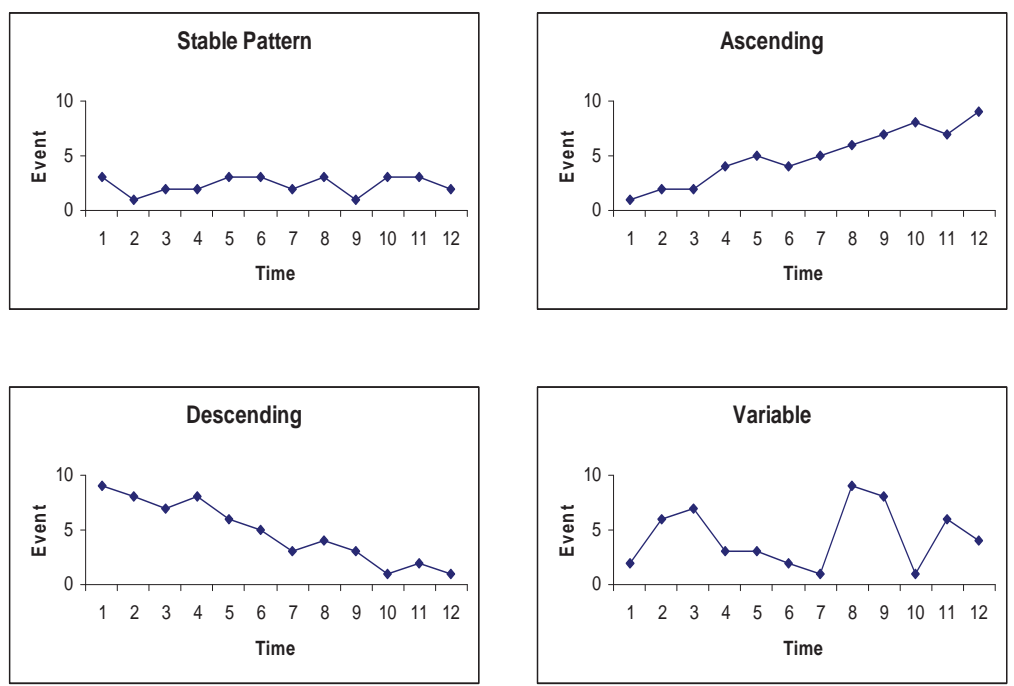

Figure 1. The four baseline trends are represented above.

\section{Functional Assessment}

While students reviewed the literature and conducted baseline observations, they also analyzed the environment where the behavior occurred. This helped them to identify stimuli that might be related to the behavior. With the information they had gathered from the literature and their own direct observation of the behavior, they would then select a treatment that they judged to have an impact upon the behavior. This process is called Functional Assessment (Barlow \& Hersen, 1984).

\section{Experimental Methodology}

Each student was taught the logic of single-subject methodology. They were required to select a design from the following selections: Withdrawal, Reversal, Multiple Baseline, Changing Criterion, and Alternating Treatment Design (Cooper, Heron, \& Heward, 1987). This selection required them to become familiar with each design, evaluating which would fit best for their self-experiment, and then apply that design. According to Barlow and Hersen (1984), the logic of singlesubject methodology is that of repeated measure over time of a targeted behavior(s). As with the baseline logic, each student monitors the graphed trend(s) of his/her targeted behavior(s) and then intervenes when indicated by a stable trend or trends. Barlow and Hersen also indicated that this methodology allows the investigator the flexibility to administer and withdraw the treatment at any give time. This enables the investigator to observe the trends of the behavior as the intervention is put in place and then withdrawn. It also gives flexibility to the investigator when a treatment does not work. That treatment can be withdrawn and once a new baseline is established, a new treatment can be introduced. When a single-subject design is used consistently, it demonstrates internal validity. In other words, there is good evidence that the treatment change is not simply correlation, but suggests causation as well. This approach focuses only on the individual. The results cannot be generalized to anyone else, but they can demonstrate validity of treatment to the individual in question. 


\section{Examples of Student Work}

Two examples of self-experiments completed in classes at Park University can be found in Appendix A and B. These examples are included as they were submitted, with few editorial changes.

\section{Decreasing Smoking Behavior}

The author of this paper completed a smoking cessation self-experiment. The entire paper was submitted for class and is included in Appendix A. She restricted her smoking to odd hours of the day; she would pay herself $\$ 1.00$ each odd hour she did not smoke. She used a Withdrawal Single-Subject Design with $A B A B$ conditions (see graph in Appendix A). The A axis stands for Baseline and the $B$ axis stands for the treatment condition. She ended with four weeks of follow-up probes without intervention. Her smoking rate remained at zero cigarettes per day. The logic of comparing a baseline, a treatment condition, another baseline, and a final treatment condition suggest that the change in behavior was more than correlational (Cooper, Heron, \& Heward, 1987).

\section{Fruit Intake Increase}

The author completed a self-experiment in which he increased the amount of fruit he ate during the day. He developed a list of rewards that could be delivered on a weekly basis for meeting his goal for the week. The menu included such things as going out to various recreational activities, shooting pool, etc. He used a Changing Criterion Single Subject Design (Appendix B) that allowed for goal setting and then goal accomplishment. The logic of the design suggests that step or goal is controlled, that control evidences causation rather than correlation (Cooper, Heron, \& Heward, 1987).

\section{Self-Experiment Rubric}

A scoring rubric is included as Appendix C. This rubric shows what was expected of the students and how many points were assigned fore ach item. It was developed to be specific and, where possible, quantifiable.

\section{Discussion}

The students who completed a self-experiment using single-subject design methodology will be able to use critical thinking at every level. Each student was required to apply knowledge from the class; analyze information from the literature; synthesize this information with behavior observations; and evaluate the process. These evaluations always led to further analysis, synthesis, etc. This project was also a meaningful because undergraduate psychology students began to gain a sense of empathy for those who are required to change their behaviors. Once a student has tried to change his/her own behavior, he/she can see how difficult change can be. This type of

Each student was required to apply knowledge from the class; analyze information from the literature; synthesize this information with behavior observations; and evaluate the process. These evaluations always led to further analysis, synthesis, etc.

research also prepares those going on to graduate school to start thinking in terms of empirical study and dissemination. In fact, a similar assignment given by the first author to a student in Oklahoma is currently in press with Clinical Case Studies (Finley \& Cowley, In Press). 
There are several ways that this project as presented could better assess critical thinking. Readers will note in the rubric that there are no specific measures to evaluate the critical thinking students engage in to complete their functional assessment. This assessment requires students to assimilate information from the literature, their baseline, and their own observations of the environment. They are then required to analyze this information to identify stimuli in the environment that influence the target behavior. This leads to the selection of a treatment. The rubric needs to be further developed to include an assessment of the critical thinking that goes into functional assessment.

\section{References}

Altman, L. K. (1986). Who goes first? Berkley, CA: University of California Press.

Barlow, D. H. \& Hersen, D. (1984). Single case experimental designs: Strategies for studying behavior change. New York: Pergamon.

Bissell, A. N. \& Lemons, P. P. (2006). A new method for assessing critical thinking in the classroom.

Bioscience, 56, 66-72.

Cooper, J. O., Heron, T. E., \& Heward, W. L. (1987). Applied behavior analysis. Columbus, $\mathrm{OH}$ : Merrill.

Finley, C. L. \& Cowley, B. J . (In Press). The effects of a consistent sleep schedule on time taken to achieve sleep. $\underline{\text { Clinical Case Studies. }}$
Fisher, E. M. \& Riley, T. A. (2005). Fostering the scholarship of discovery and integration for advanced practice education. Nursing Education Perspectives, 26, 348-350.

Roberts, S. \& Neuringer, A. (1998). Self-experimentation. In K. A. Lattal and M. Perone (Eds.), Handbook of Research Methods in Human Operant Behavior (pp. 619-655). New York: Plenum.

Robinson, C. F. \& Kakela, P. J. (2006). Creating a space to learn: A classroom of fun, interaction, and trust. College Teaching, 54, 202206.

van Gelder, T. (2005). Teaching critical thinking: Some lessons from cognitive science. College Teaching, $53,41-46$.

Cowley is an Associate Professor of Developmental Psychology at Park University, where he teaches classes in human development, learning, applied behavior analysis, parenting, and history of psychology. Cowley is also involved in the University's course assessment initiative. Cowley received his BS in Psychology from Utah State University, with a minor in Music; his MS in Behavior Analysis and Therapy from Southern Illinois University at Carbondale; and his PhD in Developmental and Child Psychology from the University of Kansas. His current research interests are in the areas of Combinatorial Entailment and Relational Frame Theory; emerging interests include adult development, in particular health aging. 
Using Functional Assessment to Decrease Smoking Behavior

Ann Lindgren

Brian J. Cowley

Park University

In this self-experimentation I reduced my smoking behavior by using a Differential Reinforcement Schedule of Other Behavior with a Fixed-Interval reinforcement delivery. Smoking was only allowed during the odd hours of the day between 7:00am and 11:00pm; for every odd hour in which I did not smoke I rewarded myself with a dollar. A Single-Subject Withdrawal Design was used ( $A B A B$ ) to establish treatment validity. The results confirm that limiting access to cigarettes and rewarding for abstinence from smoking can be an effective way to decrease smoking behavior.

The 2000 Surgeon General Report shows that an estimated $70 \%$ of smokers (33.2 million) want to quit, but only $2.5 \%$ ( 1.2 million) per year succeed in quitting smoking permanently.

According to the Centers for Disease Control (2000), $41 \%$ of smokers nationwide make an attempt to quit smoking. There are a variety of methods available to help smokers stop smoking. Effective strategies for treating tobacco use include brief advice by medical providers, counseling, and pharmacotherapy (Surgeon General, 2000) Nicotine chewing gum, nicotine patches, nicotine inhaler, nasal sprays, and some antidepressant medications like Bupropen SR, are some of the popular pharmacotherapy methods used (Krohn, Goetz, 2005).

There are also a several behavioral strategies that have shown to reduce smoking behavior, such as; selective limitation of cigarettes, increasing the interval between cigarettes (Carpenter, Hughes, Solomon, \& Calla, 2004), contingency management (Roll, 2005; Stitzer, Rand, Bigelow, Mead. 1986; Stitzer, Bigelow, 1984 ), and operant conditioning (Azrin, Powell. 1968). Carpenter, Hughes, Solomon, and Callas (2004) found that smoking reduction procedures produced better results then stage-matched intervention, motivational interviewing, and brief advice. In John Roll's study (2005) with adolescent smokers, contingency management showed to be a successful way to reduce smoking in adolescence. Contingent monetary payment based on breath carbon monoxide level has resulted in smoking behavior change; the extent of the smoking reduction has been related to the monetary value of the reinforcement offered and to the reduction target that is reinforced (Stitzer, Rand, Bigelow, Mead. 1986). An earlier study by Stitzer and Bigelow (1984) showed that when participants were only tested for carbon monoxide at a certain time of the day, their smoking at other times of the day increased, though, overall there was still a reduction of cigarette smoking. It appears that payment and monitoring procedures can be used to promote sustained smoking abstinence.

Azrin and Powell (1968) used operant conditioning to reduce the amount of cigarettes smoked by their participants. They did this by designing a cigarette case that could be locked and had a timer on it; once a cigarette was removed from the case, the case would lock for a period of time, another cigarette could only be removed after the end of the period of time. They found that limiting access to cigarettes reduced the amount of cigarettes smoked by their participants. More recently, many businesses have been prohibiting on premises smoking. Bauer et al (2005) did a study to assess the impact of smoke-free worksite policies on smoking cessation behaviors. Smoke-free policies have been shown to discourage smoking, reduce smoking consumption, and increase people's desire to quit smoking. These studies show that when people are limited to when they can smoke they decrease the amount they will smoke. I based my treatment design on the idea that limiting access to cigarettes and rewarding for abstinence from smoking would decrease my smoking behavior.

InSight: A Collection of Faculty Scholarship 
The following study uses a single-subject design and self-experimentation, done for a college class, to change my own smoking behavior. I used a fixed interval differential reinforcement of other behavior treatment design (ABAB). I did so, by only allowing myself to smoke cigarettes during odd hours of the day between $7 \mathrm{am}$ and $11 \mathrm{pm}$; for every odd hour that I did not smoke I rewarded myself with a dollar. I used event recording for measurement by tallying every cigarette I smoked, how much of the cigarette I smoked, and what time of the day I smoked it.

\section{Method}

\section{Participant}

I am a 23-year-old Caucasian female. I have been smoking cigarettes since the age of 15 , but have made several attempts to quit in the past. For most of my past cessation attempts I used a nicotine patch for approximately one week to four weeks. Though each attempt was successful, I continued to return to smoking within a year of quitting. I had been smoking for approximately six months prior to this study.

I considered myself a light smoker, smoking less then a half a pack of cigarettes a day. Most of my smoking took place in the garage at my house; I also smoked in my vehicle while driving, and occasionally smoked in restaurants or on the college campus. When I smoked at home I mostly only smoked a half of a cigarette a time. I would smoke the cigarette half way down, then leave the other half to smoke down completely at a later time. Most of the time when I smoked in my vehicle I would smoke an entire cigarette, because it was inconvenient to put it out half way.

Material

I used event recording to record the frequency of my smoking behavior. I did this by keeping a notepad and pencil with my pack of cigarettes, every time I smoked I wrote down what the time was and how much of the cigarette I smoked. I recorded the time of day I smoked to see if any patterns immerged in my smoking behavior. At the end of each day I recorded the amount of cigarettes smoked during that day on a chart.

My reinforcement involved rewarding myself with a dollar. Since I did not have dollars readily available on hand, I used dried beans to keep track of each dollar earned. The dried beans were kept in a baggy so I could add them up at the end of treatment, and deduct that dollar amount from my savings account for spending. After the extinction of my treatment plan I will do a once a week maintenance probe to check for a relapse of behavior. I will collect data every Monday for one month.

\section{Design and Procedure}

I took baseline for eighteen days, smoking an average of 6.3 cigarettes a day, with a maximum of 8 and a minimum of 5 . I found no real pattern in the times of days I would smoke, thus there were no external factors that caused my behavior. I used this information to determine what my fixed intervals for my treatment schedule.

I used a fixed interval reinforcement schedule by only allowing my self to smoke during the odd hours of the day. I typically slept from 12:00am to 7:30am, so I limited my available reinforcement hours to the odd hours of and between 7:00am and 11:00pm. During these odd hours I allowed myself to smoke as many cigarettes as I desired. The assessment was the same; I kept the notepad and pencil with the pack of cigarettes, and wrote down the time and amount smoked. I used a differential reinforcement of other behavior; for every hour I did not smoke I would reward myself with a dollar. I used an ABAB withdrawal treatment design, with an eighteen-day baseline, a seven-day treatment, a five-day return to 
baseline, followed by fifteen days of treatment that ended in extinction. One variable that occurred on day 34 was a dental visit in which I had oral surgery. The dentist advised me not to smoke during the healing process.

\section{Results}

During the first treatment condition I reduced my smoking from a baseline average of 6.3 cigarettes a day, to an average of 3.5 cigarettes a day. I started treatment smoking 4.5 cigarettes, and made a steady seven-day decline ending at 2.5 cigarettes. I then returned to baseline, and my smoking increased to an average of 3.9 cigarettes per day, which was up slightly from my treatment average of 3.5, but not as high as my pretreatment average of 6.3. I returned to treatment, and my daily smoking immediately dropped back down, and after the fourth day of treatment I had quit smoking. After my smoking behavior had decreased to zero cigarettes, I continued treatment for eleven days before extinction of reinforcement. On day 34, the day before my behavior dropped to zero cigarettes, was my oral surgery, and I took my doctor's advice to refrain from smoking.

\section{Discussion}

This study showed that reduction procedures accompanied by reinforcement can lead to smoking cessation. There have been many pervious studies that have shown the effectiveness of using money as reinforcement for smoking abstinence (Stitzer and Bigelow, 1984. Roll, 2005. Stitzer, Rand, Bigelow, and Mead, 1986). Azrin and Powell (1968) showed the effectiveness of restricting the amount of cigarettes smoked by using a reduction technique. Though the procedure was successful in reducing the amount of cigarettes smoked by all participants, there was no reinforcement for the smoking reduction, so the participants went back to smoking as usual as soon as the study was over (Azrin, Powell, 1968). It seemed to me that if I restricted when I allowed myself to smoke, and added reinforcement as an incentive not to smoke, that I might achieve cessation.

Something that my treatment design is missing which would greatly improve its validity is interobserver agreement percentages. When I began collecting the data I was using permanent product by collecting the cigarette butts and writing down what time I smoked the cigarette. It didn't take me long to realize I was being repetitive in my collection methods, so I switched to just tallying (event recording) the occurrence of my behavior. However, I did not find out until it was too late that tallying the occurrence of a behavior could not be considered permanent product, and therefore could not be used for introbserver agreement. Though I have every piece of paper in which I recorded the occurrence of my behavior, since it was event recording and I did not have anyone present during each occurrence of my behavior, I was unable to use the information to establish a percentage of introbserver agreement.

In setting up my design I took in consideration the amount of cigarettes I smoked, and how often I smoked. Though I was only averaging six cigarettes a day, I would mostly smoke half cigarettes, which made the frequency at which I smoked much greater then if I had smoked whole cigarettes. I decided if I were to limit myself to only smoking every other hour it would work to reduce my smoking, and wouldn't put to much pressure on me in withdrawing from the addictive nature of cigarette smoking. I chose an odd hour restriction because it fit conveniently into my weekly schedule, most often I was in my vehicle at nine in the morning, and in my vehicle was my favorite place to smoke. I also knew that at anytime during the day that I really wanted to smoke, I would never have to wait more then an hour for that chance, and most of the time this occurred, when the hour came that I could smoke, the desire had gone away. When repeating this study on other smokers it would be necessary to set up time slots that would be convenient for their schedules. Since I was a light smoker it was easy for me to restrict myself to 
an every other hour schedule, but a heavier smoker may need a shorter limitation. Also, the hours that are chosen should be convenient for a person's schedule, for instance; if the participant gets an hour lunch break at work, don't make that one hour a restricted hour.

A variable that affected the final cessation of my smoking behavior was oral surgery during the last bit of my treatment. Because of the surgery, I was advised not to smoke, so I took the advice and quit smoking. After going several days without smoking it made it much easier to continue on with that pattern. However, prior to the surgery I was only smoking 1.5 cigarettes a day, and the likelihood that I would have reduced that to zero regardless of surgery, was very high.

For reinforcement I chose a dollar because it was a realistic amount for me to receive. It gave me incentive because there is many things I have been wanting to buy, and haven't set the money aside to do so. I chose the dollar amount, because that led to the potential of nine dollars a day, which could add up to a decent amount. When using this procedure on a smoker it would be important to set up a reinforcement that would be beneficial for them, that way they feel motivated to abstain from smoking during the allotted time.

The way I set up this procedure made it very easy on me throughout the whole process. I never felt pressured or agitated that I couldn't smoke, my withdrawal symptoms were minimum, and it caused virtually no disruption in my daily routine. I can easily say, this quitting experience was far more enjoyable and easier then my past quitting experiences with the nicotine patch or gum.

This study supports that functional assessment is effective in reducing smoking behavior. This single subject design combined reduction and reinforcement to treat smoking behavior. It showed that self-management can be an effective way to stop smoking; this can be achieved by reducing the times you allow yourself to smoke and rewarding yourself for not smoking. This study can be replicated in many numbers of ways, to fit an individual smoker's needs.

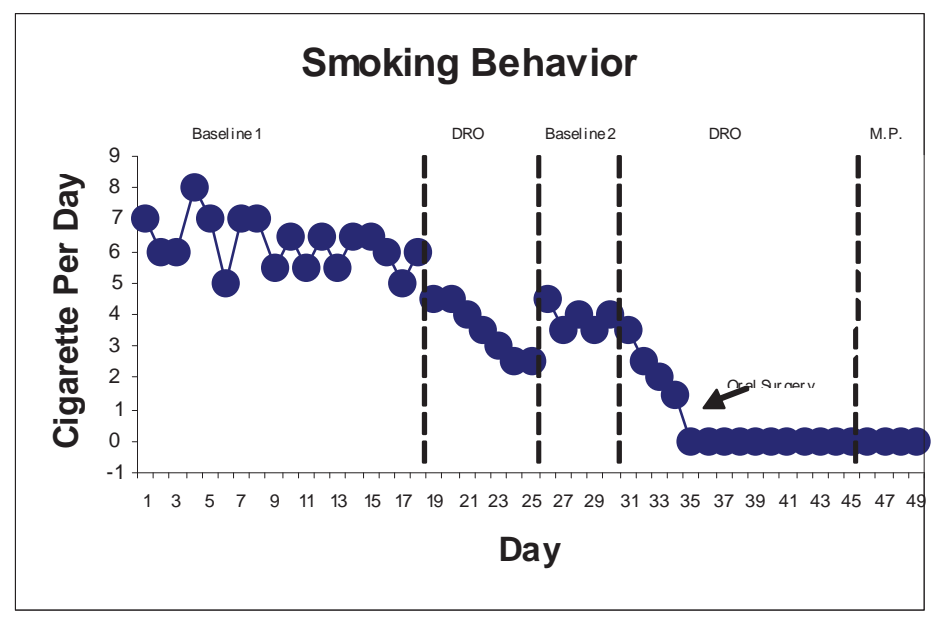

\section{References}

Azrin, N., \& Powell, J. (1968).

Behavioral engineering: the reduction

of smoking behavior by a conditioning apparatus and procedure. J ournal of Applied Behavior Analysis, 1(3), 193-200.
Bauer, J. Hyland, A. Li, O. Steger, C. Cummings, K. (2005). A longitude assessment of the impact of smokefree worksite policies on tobacco use. American Journal of Public Health, 95(6). 1024-1030. 
Carpenter, M., Hughes J., Solomon L., and Callas, P. (2004). Both smoking reduction with nicotine replacement therapy and motivational advice increase future cessation among smokers

unmotivated to quit. Journal of Consulting and Clinical Psychology, 72(3), 371-381.

Krohn, F., \& Goetz, K. (2005). The Goetz plan: a practical smoking cessation program for college students. College Student Journal, 39(2), 260-268.

Roll, J. (2005). Assessing the feasibility of using contingency management to modify cigarette smoking by adolescents. Journal of Applied Behavior Analysis, 38(4), 463-467.
Stitzer, M., \& Bigelow, G. (1984). Contingent reinforcement for carbon monoxide reduction: within-subject effects of pay amount. Journal of Applied Behavior Analysis, 17(4), 477-483.

Stitzer, M., Rand C., Bigelow G., and Mead, A. (1986). Contingent payment procedures for smoking reduction and cessation. J ournal of Applied Behavior Analysis, 19(2), 197-202.

Surgeon Generals Report. (2000). Reducing tobacco use: A report of the surgeon general. (Stock Number 017-023-00204-0). Retrieved. March 25, 2006. From National Center For Chronic Disease Prevention and Health Promotion via GPO Access: http://www.cdc.gov/tobacco/sgr/inde x.htm.

Lindgren is currently an honor roll student at Park University, with plans to graduate in Spring 2007 with a BA in Psychology. Before coming to Park University, Lindgren earned an AA from Maple Woods Community College, where she graduated with honors. After graduating from Park University, Lindgren plans to continue her studies in a graduate program, eventually earning at PhD in Psychology with a focus on health psychology. 
I ncreasing the Amounts of Fruit Ingested to Promote a Healthy Diet David Langdon

Brian J. Cowley

Park University

The increasing rate of obesity in people represents a major public health concern especially since obesity is correlated with an increased rate of morbidity and mortality. The cause of obesity results when caloric intake exceeds the burning of calories. Obesity is directly related to diet, however it is difficult for one to change and maintain their diet. These difficulties in maintaining healthy eating are not surprising because obese persons find high-fat foods more reinforcing than lower fat foods. This coupled with the fact that healthy changes in eating behavior are generally not maintained over time can make changing diet a very difficult task. (Goldfield \& Epstein, 2002). Another factor contributing do the difficulty of diet is that unlike health-related habits that are optional features of one's lifestyle, food consumption is central to everyday survival. Therefore, dietary interventions have an air of ambivalence (Kumanyika, Van Horn, Bowen, \& Perri 2000).

In order to counteract obesity a proper diet is in order. A major part of a healthy diet and which is lacking in many adults are fruits. Fruits are a very healthy and part of a balanced nutrition. Vegetables and fruit are important sources of several essential nutrients, including vitamin $\mathrm{C}$, folate and other B vitamins, provitamin $\mathrm{A}$ and other carotenoids, potassium, calcium, and iron (National Cancer Institute, 2006). Fruits, in addition also help in reducing calories, and have positive health benefits. Advice to increase intake of fruits and vegetables is based on epidemiologic studies indicating that an eating pattern high in fruits and vegetables is protective against cancer and CVD dietary modification for cardiopulmonary risk reduction converges around increased intake of fruits and vegetables. The evidence was most conclusive for vegetables and fruit in prevention of cancers are in cancers of the mouth and pharynx, esophagus, lung, and stomach (National Cancer Institute, 2006). The protective effect of fruit and vegetable consumption was found in 128 of 156 dietary studies in which results were expressed in terms of relative risk. In the majority of cancer sites people who consume low amounts of fruits and vegetables experience around double the risk of cancer compared with those with high intake. (Block, Patterson, \& Subar, 1992). Higher fruit and vegetable consumption of between 9 and 12 servings per day have shown to reduce blood pressure by a large sum.

In order to increase the behavior of fruit consumption the goals were set on a single-subject changing criterion design schedule. These goals were reinforced with a menu of variable rewards. Changing criterion design was first described in applied behavior analysis in two papers coauthored by Hartmann and Hall (1976). This design has been used in the past on a single target behavior schedule (Cooper, Heron, \& Heward 1987). The changing criterion design is a variation of a multiple baseline with treatment introduced in a series of phases. Each treatment phase is associated with a step like change in criterion rate for the target behavior. This means that each phase of the design provides the baseline for the next phase. When the target behavior changes with each step in criterion, therapeutic change is replicated and experimental change determined. (Hartmann \&Hall 1976) The reason change in criterion design was used is that goals and expectations matched up perfectly with the criterion set up by Hartmann and Hall to successfully use this treatment program. The length of the baseline, number of treatment phases, and magnitude of treatment phases were all set up so as to be naturally occurring in accordance with Hartmann and Hall. The benefit of the changing criterion design is that the starting criterion is base upon the subject's own personal baseline and treatment is therefore given in small successful increments followed by reward (De Luca \& Holborn, 1992). The intention of this treatment is to have the participant 
consume the set goal of number of servings each week until the participant reaches the goal of 5 servings of fresh fruit in accordance to the National 5-a Day program.

\section{Method}

The participant in this experiment was I, a 21 year old senior in from Park University. I have not been consuming the daily recommended servings of fruit. In order to increase my consumption of fresh fruit I used a single subject self-change project using a changing criterion design with a menu of rewards (Cigar, Hen House Chinese Food, Argosy Casino Buffet, \& Shoot Pool with Friends, Go out to a New Movie with Fiancé). I established a baseline by recording the number of fresh fruit servings I had consumed per day. My baseline for fresh fruit consumption was zero. After baseline was established a treatment of a changing criterion design was introduced in which if I consumed one serving of fresh fruit a day for a week a reward would be given from the menu. After each week of completion the number of servings increased by one until 5 servings of fresh fruit a day was reached. I measured my fresh fruit consumption using a semi-permanent product system in which the core or peel of a fruit was kept after every fresh fruit consumed and then counted that night and thrown away. The interobserver reliability for this experiment was my fiancée Heather who observed me consuming fresh fruit on a daily basis.

\section{Results}

The results of this data is that the baseline of zero fresh fruit servings consumed increased to 1 serving per day for 7 days after the treatment was implemented (See Figure 1). On the eighth day of treatment the number of servings consumed was increased to 2 servings per day for 7 days and a reward was given for the completion of the prior week's goal. On the fifteenth day of treatment the number of servings was increased to 3 servings per day for 7 days and a reward was given for the completion of the prior week's goal. On the 22nd day of treatment the number of servings was increased to 4 servings per day for 7 days and a reward was given for the completion of the prior week's goal. On the $29^{\text {th }}$ day of treatment the number of servings was increased to 5 servings per day for 7 days and a reward was given for the completion of the prior week's goal. After the completion of the $5^{\text {th }}$ week where 5 servings of fruit were consumed per day the treatment was discontinued and probes were implemented once a week in order to determine if there was a return to baseline. The probes reflected a decrease in fruit consumption, but not a complete return to baseline was recorded.

\section{Discussion}

The Reinforcements and goal structure as described by Hartmann and Hall (1976) was successful in this study to increase fresh fruit consumption. The effectiveness of this design relies in the reward system and the variability of the rewards in order to prevent satiation. By establishing a menu of rewards in which I was to choose from at the end of each weak provided adequate motivation for me to continue my goal of consuming fresh fruit. Without the reward system having variability I most likely would not have reached my goal.

The benefits of increased fresh fruit consumption are very noticeable after a relatively short time of only 4 and $1 / 2$ weeks. I've noticed I feel better and more energized the more I eat fresh fruit and that I have begun to enjoy the taste of fruit much more since I have started this project. Another upside to the increase amount of fresh fruit is the downside of less healthy snack food such as cookies, cakes, and sugary snacks. In order to reach my goals in the latter weeks of this project I had to eat less of the snack food and more fruit. This experiment has shown how successful changing criterion design can be used in increasing healthy eating. If this is combined with De Luca and Holburn's (1992) study where they used changing 
criterion to increase exercise in the obese it could dramatically increase the heath of those who use this design for treatment.

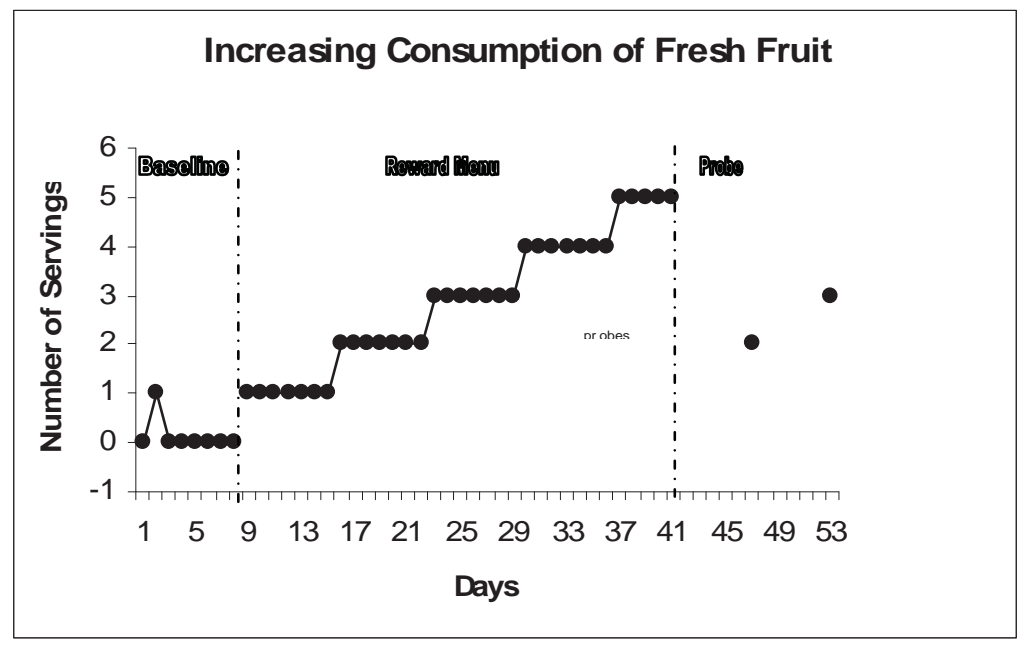

\section{References}

Block, G., Patterson, B., \& Subar A. (1992). Fruit, vegetable, and cancer prevention: a review of the epidemiological evidence. Nutrition and Cancer, 18(1), 1-29.

Cooper, J., Heron, T., \& Heward, W. (1987). Applied behavior analysis. 1st ed. Upper Saddle River, NJ : Prentice Hall.

De Luca, R., \& Holborn, S. (1992). Effects of a variable-ratio reinforcement schedule with changing criteria on exercise on obese and nonobese boys. Journal of Applied Behavioral Analysis, 25(3), 671-679.
Goldfield, G., Epstein, L., \& . (2002) Can fruits and vegetables and activities substitute for snack foods? Health Psychology, 21(3).

Hartmann, D., \& Hall, V. (1976). The changing criterion design. J ournal of Applied Behavioral Analysis, 9(4), 527-532.

Kumanyika , S., Van Horn L., Bowen D., and Perri, M. (2000).

Maintenance of dietary behavior change. Health Psychology, 19(1s), 42-56.

National Cancer Institute, (2006.). Cancer control and population sciences. Retrieved Mar. 14, 2006, from 5 a day for better health program evaluation Web site: http://cancercontrol.cancer.gov/ 5ad 2 evi.html. 


\begin{tabular}{|c|c|c|c|c|}
\hline Competency & $\begin{array}{c}3 \\
\text { Exceeds } \\
\text { Expectation }\end{array}$ & $\begin{array}{c}2 \\
\text { Meets } \\
\text { Expectation } \\
\end{array}$ & $\begin{array}{c}1 \\
\begin{array}{c}\text { Does Not Meet } \\
\text { Expectation }\end{array} \\
\end{array}$ & $\begin{array}{c}0 \\
\text { No } \\
\text { Evidence } \\
\end{array}$ \\
\hline $\begin{array}{l}\text { Critical } \\
\text { Thinking }\end{array}$ & $\begin{array}{l}\text { Up to } 100 \% \text { of the points } \\
\text { Possible }\end{array}$ & $\begin{array}{l}\text { Up to } 70 \% \text { of the points } \\
\text { Possible }\end{array}$ & $\begin{array}{l}\text { Up to } 50 \% \text { of the points } \\
\text { Possible }\end{array}$ & $\begin{array}{l}\text { Up to } 30 \% \text { of the points } \\
\text { Possible }\end{array}$ \\
\hline $\begin{array}{l}\text { Synthesis } \\
\text { Outcomes } \\
2,3,4\end{array}$ & $\begin{array}{l}\text { In the introduction of the } \\
\text { paper, the student used: } \\
\text { - } 8 \text { or more references } \\
\text { from the literature. } \\
\text { - The student cited } \\
\text { references that } \\
\text { provide evidence } \\
\text { from the literature on } \\
\text { the topic being } \\
\text { examined in the } \\
\text { introduction and } \\
\text { discussion. } \\
\text { Three of the } \\
\text { references should be } \\
\text { empirical and } \\
\text { refereed research } \\
\text { articles. ( } 35 \\
\text { Points) }\end{array}$ & $\begin{array}{l}\text { In the introduction of the } \\
\text { paper, the student used: } \\
\text { 5-7 references from } \\
\text { the literature. } \\
\text { The student cited } \\
\text { references that } \\
\text { provide evidence } \\
\text { from the literature } \\
\text { on the topic being } \\
\text { examined in the } \\
\text { introduction and } \\
\text { discussion. } \\
\text { Three of the } \\
\text { references should } \\
\text { be empirical and } \\
\text { refereed research } \\
\text { articles. (24.5 } \\
\text { Points) }\end{array}$ & $\begin{array}{l}\text { In the introduction of the } \\
\text { paper, the student used: } \\
\text { 1- reference(s) from } \\
\text { the literature. } \\
\text { The student cited } \\
\text { references that } \\
\text { provide evidence } \\
\text { from the literature on } \\
\text { the topic being } \\
\text { examined in the } \\
\text { introduction and } \\
\text { discussion. (17.5 } \\
\text { Points) }\end{array}$ & $\begin{array}{l}\text { In the introduction of the } \\
\text { paper, the student did not use } \\
\text { any references from the } \\
\text { literature. } \\
\text { (10.5 Points) }\end{array}$ \\
\hline $\begin{array}{l}\text { Analysis } \\
\text { Outcomes } \\
2,3,4\end{array}$ & $\begin{array}{l}\text { In the introduction the } \\
\text { student used the } \\
\text { information gleaned from } \\
8 \text { or more references to } \\
\text { build an argument to } \\
\text { validate the treatment } \\
\text { method they used in the } \\
\text { Behavior Self-Change } \\
\text { Project. (40 points) }\end{array}$ & $\begin{array}{l}\text { In the introduction the } \\
\text { student used the } \\
\text { information gleaned from } \\
\text { the } 5-7 \text { references to } \\
\text { build an argument to } \\
\text { validate the treatment } \\
\text { method they used in the } \\
\text { Behavior Self-Change } \\
\text { Project. (28 Points) }\end{array}$ & $\begin{array}{l}\text { In the introduction the } \\
\text { student used the } \\
\text { information gleaned from } \\
\text { the } 1-4 \text { reference }(s) \text { to build } \\
\text { an argument to validate the } \\
\text { treatment method they used } \\
\text { in the Behavior Self-Change } \\
\text { Project. ( } 20 \text { Points) }\end{array}$ & $\begin{array}{l}\text { In the introduction the student } \\
\text { did not use any information } \\
\text { gleaned from the literature to } \\
\text { build an argument to validate } \\
\text { the treatment method they } \\
\text { used in the Behavior Self- } \\
\text { Change Project. (12 Points) }\end{array}$ \\
\hline $\begin{array}{l}\text { Evaluation } \\
\text { Outcomes } \\
2,3,4\end{array}$ & $\begin{array}{l}\text { In the introduction the } \\
\text { student has identified } \\
\text { what treatment they will } \\
\text { be using. In the } \\
\text { conclusion, the student } \\
\text { has indicated how their } \\
\text { research will add to the } \\
\text { body of literature } \\
\text { outlined in their } \\
\text { introduction. In the } \\
\text { conclusion, the student } \\
\text { has indicated how their } \\
\text { research could be } \\
\text { improved. (40 points) }\end{array}$ & $\begin{array}{l}\text { In the introduction the } \\
\text { student has identified } \\
\text { what treatment they will } \\
\text { be using. In the } \\
\text { conclusion, the student } \\
\text { has indicated how their } \\
\text { research will add to the } \\
\text { body of literature } \\
\text { outlined in their } \\
\text { introduction. ( } \mathbf{2 8} \\
\text { Points) }\end{array}$ & $\begin{array}{l}\text { In the introduction the } \\
\text { student will identify what } \\
\text { treatment they will be using. } \\
\text { ( } 20 \text { Points) }\end{array}$ & $\begin{array}{l}\text { In the introduction, the } \\
\text { student failed to identify what } \\
\text { treatment they will be using. } \\
\text { (12 Points) }\end{array}$ \\
\hline \multicolumn{5}{|l|}{ Content } \\
\hline $\begin{array}{l}\text { Terminology } \\
\text { Outcome } \\
1\end{array}$ & $\begin{array}{l}\text { The student will use } 16 \\
\text { or more vocabulary } \\
\text { words specifically used in } \\
\text { the field of Behavior } \\
\text { Analysis. Not only are } \\
\text { these words used, but } \\
\text { they are used } \\
\text { consistently and } \\
\text { accurately. ( } 35 \text { Points) }\end{array}$ & $\begin{array}{l}\text { The student will use 10- } \\
15 \text { vocabulary words } \\
\text { specifically used in the } \\
\text { field of Behavior Analysis. } \\
\text { Not only are these words } \\
\text { used, but they are used } \\
\text { consistently and } \\
\text { accurately. ( } 24.5 \\
\text { Points) }\end{array}$ & $\begin{array}{l}\text { The student will use 1-9 } \\
\text { vocabulary words specifically } \\
\text { used in the field of Behavior } \\
\text { Analysis. Not only are these } \\
\text { words used, but they are } \\
\text { used consistently and } \\
\text { accurately. (17.5 Points) }\end{array}$ & $\begin{array}{l}\text { The student did not use } \\
\text { vocabulary words specifically } \\
\text { used in the field of Behavior } \\
\text { Analysis. Not only are these } \\
\text { words not used, but they are } \\
\text { not used consistently and } \\
\text { accurately. (10.5 Points) }\end{array}$ \\
\hline $\begin{array}{l}\text { Concepts } \\
\text { Outcome } \\
1,2,3,4\end{array}$ & $\begin{array}{l}\text { The student } \\
\text { demonstrates a correct } \\
\text { understanding of } \\
\text { operant conditioning } \\
\text { principles, functional } \\
\text { assessment, and } \\
\text { single-subject design } \\
\text { as they are applied in } \\
\text { their study. The } \\
\text { student has identified a } \\
\text { novel treatment } \\
\text { concept as result of the } \\
\text { functional assessment } \\
\text { and search of the } \\
\text { literature. (40 } \\
\text { Points) }\end{array}$ & $\begin{array}{l}\text { The student } \\
\text { demonstrates a correct } \\
\text { understanding of } \\
\text { operant conditioning } \\
\text { principles, functional } \\
\text { assessment, and } \\
\text { single-subject design } \\
\text { as they are applied in } \\
\text { their study. ( } 28 \\
\text { Points) }\end{array}$ & $\begin{array}{l}\text { The student uses operant } \\
\text { conditioning principles, } \\
\text { functional assessment, and } \\
\text { single-subject design as } \\
\text { they are applied in their } \\
\text { study. (20 Points) }\end{array}$ & $\begin{array}{l}\text { The student does not use } \\
\text { operant conditioning } \\
\text { principles, functional } \\
\text { assessment, and single- } \\
\text { subject design as they are } \\
\text { applied in their study. ( } \mathbf{1 2} \\
\text { Points) }\end{array}$ \\
\hline
\end{tabular}




\begin{tabular}{|c|c|c|c|c|}
\hline Competency & $\begin{array}{c}3 \\
\text { Exceeds } \\
\text { Expectation }\end{array}$ & $\begin{array}{c}2 \\
\text { Meets } \\
\text { Expectation }\end{array}$ & $\begin{array}{c}1 \\
\text { Does Not Meet } \\
\text { Expectation }\end{array}$ & $\begin{array}{c}0 \\
\text { No } \\
\text { Evidence }\end{array}$ \\
\hline \multicolumn{5}{|l|}{$\begin{array}{l}\text { Content } \\
\text { (Cont'd) }\end{array}$} \\
\hline $\begin{array}{l}\text { Application } \\
\text { Outcomes } \\
3,4,6\end{array}$ & $\begin{array}{l}\text { While using the principles } \\
\text { of operant conditioning, } \\
\text { functional assessment, } \\
\text { and single-subject design, } \\
\text { the student manipulates } \\
\text { the targeted behavior. } \\
\text { The student is able to } \\
\text { show experimental } \\
\text { control. ( } 35 \text { Points) }\end{array}$ & $\begin{array}{l}\text { While using the principles } \\
\text { of operant conditioning, } \\
\text { functional assessment, } \\
\text { and single-subject design, } \\
\text { the student manipulates } \\
\text { the targeted behavior. } \\
\text { (24.5 Points) }\end{array}$ & $\begin{array}{l}\text { While using the principles } \\
\text { of operant conditioning, } \\
\text { functional assessment, } \\
\text { and single-subject design, } \\
\text { the student attempts to } \\
\text { manipulate the targeted } \\
\text { behavior. (17.5 Points) }\end{array}$ & $\begin{array}{l}\text { The student does not } \\
\text { use the principles of } \\
\text { operant conditioning, } \\
\text { functional assessment, } \\
\text { and single-subject } \\
\text { design, to manipulate } \\
\text { the targeted behavior. } \\
\text { (10.5 Points) }\end{array}$ \\
\hline \multicolumn{5}{|l|}{$\begin{array}{l}\text { Technical } \\
\text { Skills } \\
\end{array}$} \\
\hline $\begin{array}{l}\text { Whole Artifact } \\
\text { Outcome } \\
4\end{array}$ & $\begin{array}{l}\text { The Behavior Self-Change } \\
\text { Project shows a } \\
\text { consistent use of APA } \\
\text { format with there being } \\
\text { no more that } 0-4 \text { errors. } \\
\text { ( } 35 \text { Points) }\end{array}$ & $\begin{array}{l}\text { The Behavior Self-Change } \\
\text { Project shows a } \\
\text { consistent use of APA } \\
\text { format with there being } \\
\text { no more that 5-7 errors. } \\
\text { (24.5 Points) }\end{array}$ & $\begin{array}{l}\text { The Behavior Self-Change } \\
\text { Project shows a } \\
\text { consistent use of APA } \\
\text { format with there being } \\
\text { no more that 8-10 errors. } \\
\text { (17.5 Points) }\end{array}$ & $\begin{array}{l}\text { The Behavior Self- } \\
\text { Change Project does not } \\
\text { show a consistent use of } \\
\text { APA format with there } \\
\text { being no more that } 10 \\
\text { errors. ( } 10.5 \text { Points) }\end{array}$ \\
\hline \multirow[t]{2}{*}{$\begin{array}{l}\text { Component } \\
\text { Outcome } \\
4\end{array}$} & $\begin{array}{l}\text { Same as Meets } \\
\text { Expectation category, } \\
\text { except student has used } \\
\text { the computer for all } \\
\text { graphics. ( } 20 \text { Points) }\end{array}$ & $\begin{array}{l}\text { The Behavior Self-Change } \\
\text { Project contains the } \\
\text { following sections: } \\
\text { - Cover page } \\
\text { - Abstract - summary of } \\
\text { Project } \\
\text { - Introduction - contains } \\
\text { a review of the } \\
\text { literature, rationale for } \\
\text { treatment, and } \\
\text { statement of intention. } \\
\text { - Method - contains } \\
\text { participant, procedure, } \\
\text { materials, research } \\
\text { design, and } \\
\text { interobserver- } \\
\text { reliability. } \\
\text { Results - summary of } \\
\text { the data } \\
\text { Discussion - } \\
\text { statement of outcome, } \\
\text { analysis of how the } \\
\text { treatment and results } \\
\text { add to the literature, } \\
\text { and a statement of } \\
\text { how their project could } \\
\text { be improved. } \\
\text { References Page - all } \\
\text { the references in the } \\
\text { body of the text match } \\
\text { up with those in the } \\
\text { references list and all } \\
\text { references in the } \\
\text { references list match } \\
\text { up with those in the } \\
\text { body of the text. } \\
\text { Graph(s) - single- } \\
\text { subject design format } \\
\text { graph with all labels, } \\
\text { etc. (14 Points) } \\
\end{array}$ & $\begin{array}{l}\text { The Behavior Self-Change } \\
\text { Project contains only the } \\
\text { following sections: } \\
\text { - Cover page } \\
\text { - Introduction } \\
\text { - Method } \\
\text { : Results } \\
\text { - Riscussion } \\
\text { - Graph(s) (10 } \\
\text { Points) }\end{array}$ & $\begin{array}{l}\text { The Behavior Self- } \\
\text { Change Project does not } \\
\text { contain all of the } \\
\text { following sections: } \\
\text { - Cover page } \\
\text { - Introduction } \\
\text { - } \quad \text { Method } \\
\text { - } \quad \text { Results } \\
\text { - Refussion } \\
\text { - Graph(s) (6 } \\
\text { Points) }\end{array}$ \\
\hline & $\begin{array}{c}\text { Exceeds } \\
\text { Expectation }\end{array}$ & $\begin{array}{c}\text { Meets } \\
\text { Expectation }\end{array}$ & $\begin{array}{c}\begin{array}{c}\text { Does Not Meet } \\
\text { Expectation }\end{array} \\
\end{array}$ & $\begin{array}{c}\text { No } \\
\text { Evidence } \\
\end{array}$ \\
\hline $\begin{array}{l}\text { Relationship } \\
\text { Outcome } \\
4\end{array}$ & $\begin{array}{l}\text { Each section (cover page, } \\
\text { introduction, method, } \\
\text { results, discussion, } \\
\text { references page, and } \\
\text { graph) contain sufficient } \\
\text { information that this } \\
\text { research could be } \\
\text { submitted to a conference } \\
\text { or journal as is. (20 } \\
\text { Points) }\end{array}$ & $\begin{array}{l}\text { Each section (cover page, } \\
\text { introduction, method, } \\
\text { results, discussion, } \\
\text { references page, and } \\
\text { graph) contain sufficient } \\
\text { information that this } \\
\text { research could be } \\
\text { replicated by reading the } \\
\text { Behavior Self-Change } \\
\text { Project. (14 Points) }\end{array}$ & $\begin{array}{l}\text { Each section (cover page, } \\
\text { introduction, method, } \\
\text { results, discussion, } \\
\text { references page, and } \\
\text { graph) contain sufficient } \\
\text { information that you have } \\
\text { a general idea of what } \\
\text { was attempted in the } \\
\text { Behavior Self-Change } \\
\text { Project. (10 Points) }\end{array}$ & $\begin{array}{l}\text { Each section (cover } \\
\text { page, introduction, } \\
\text { method, results, } \\
\text { discussion, references } \\
\text { page, and graph) do not } \\
\text { contain sufficient } \\
\text { information that you } \\
\text { have a general idea of } \\
\text { what was attempted in } \\
\text { the Behavior Self- } \\
\text { Change Project. ( } 6 \\
\text { Points) }\end{array}$ \\
\hline
\end{tabular}

